\title{
Graduate mobility in the United Kingdom
}

\author{
from Richard Pearson \\ Increasing interest is being paid in the United Kingdom to longer-term graduate careers; several cohort
studies following graduates from 1980 and later years are now under way or are being planned.
}

Job prospects and employment patterns of new qualifying graduates are seen by many as an important indicator of higher education's "success" and relevance to industry. Others argue that they say nothing about lifetime returns from higher education which should not be exclusively jobrelated. Nevertheless, by providing an easily quantifiable indicator, trends and comparisons based on the first destination statistics will be made. While they provide a valuable barometer of initial labour market success, they are not a definitive statement of longer-term employment prospects. A typical working life lasts forty years or more and in the United Kingdom there are more than six million job changes each year. Evidence about employment status six months after graduation can provide only a starting point for assessing graduate careers.

In providing a broader context, a recently published study' of graduate mobility based on the experiences of $280 \mathrm{em}$ -

\begin{tabular}{lcccccc}
\hline \multicolumn{5}{c}{ Graduate retention 1974-79 and 1980-84 } \\
\hline Retention dates & 5 th & 4th & 3rd & 2nd & 1 st \\
& 54 & 59 & 71 & 84 & 96 \\
$1974-79$ cohort & 58 & 66 & 72 & 84 & 94 \\
$1980-84$ cohort & &
\end{tabular}

* Ist = most recent that is 1979 and 1984 respectively.

ploying organizations showed that nearly 40 per cent of graduates recruited in 1980 were no longer with the same employer five years later. As Fig. 1 shows, there is a fairly standard decay curve, with 34 per cent of the 1981 cohort and 16 per cent of the 1983 cohort having left their initial employer by 1985 . In addition, most graduates who have stayed with a single employer will also have changed jobs over this period and some will also have moved geographically. What is particularly interesting about the 1985 study is the comparison that can be made with the results of a similar study in 1980 . The time span for each was five years, and each covered a similar economic cycle from a low to a high point of economic activity. Despite the fact that the recession of the 1980s and the contraction in job opportunities was far more severe, retention rates followed kremarkably similar patterns (Fig. 1). Despite this consistency over time, there were differences between employers from different sectors. The sector with the highest loss was engineering, where 60 per cent of the 1980 graduates were no longer with their original employer five years later. This may be in part explained by the low recruitment levels in this sector in the early 1980 s resulting in a shortage of experienced graduates three to five years later which in turn encouraged mobility between employers. By contrast, only 26 per cent of those recruited by chemical companies in 1980 had left their initial employer in the following five years. More general evidence suggests that the retention curve flattens after five years or so, and that after 10 or 15 years probably 30 per cent of graduates are still with the same employer.

These studies show only general trends. The best source of data on the mobility of individual graduates remains the now dated study by the Department of Employment of 12,000 students and their careers and mobility over the seven years to 1977 . That study showed that men graduates were more mobile than women graduates, both between their occupations and type of work, but that women were more likely to move between employment sectors. The main motivation of graduates in changing jobs was the "job interest" and "level of responsibility offered" but the prospects of a good salary and promotion assumed increased importance as their careers developed. Women's salaries were about 20 per cent below those of men after seven years, a difference only partly explained by the higher incidence of part-time work among women. The highest salaries were, in 1977, paid to graduates in social studies or engineering, the lowest to arts graduates. Managerial jobs in industry and commerce tended to be the best paid, while school teachers were among the lowest paid. It was also found to be less rewarding financially seven years after graduation to have studied and gained a postgraduate qualification than to have entered employment directly and gained work experience. This study is due to be repeated next year, based on the cohort graduating in 1980 .

The most recent major survey of graduates' early careers has been that being undertaken by the Council for National Academic Awards (CNAA) which is surveying 10 per cent $(2,600)$ of graduates who received CNAA degrees in 1982. The students were surveyed in 1983, 1984 and 1985 . allowing a three-year profile to be drawn up of their early careers. The results of the 1983 survey reveal a complex pattern of transition over the first year into the labour market. They show significant numbers entering, for example, part-time or temporary employment and one in six changing their job within the first year. In many of the "vocational" subjects such as pharmacy, nursing and business studies, the graduates were in their preferred job, but 40 per cent of all graduates and 60 per cent of scientists were looking for "something better". Nearly half the scientists felt over-qualified for the job they were then doing and one in six scientists had already had two or more jobs in their first year after graduation. A further 41 per cent had considered changing jobs. Nearly a year after graduation, the average salary for a scientist in 1983 was $£ 4,867$, considerably below that of engineers $(£ 6,358)$ and maths/ computer scientists $(£ 6,354)$ but similar to

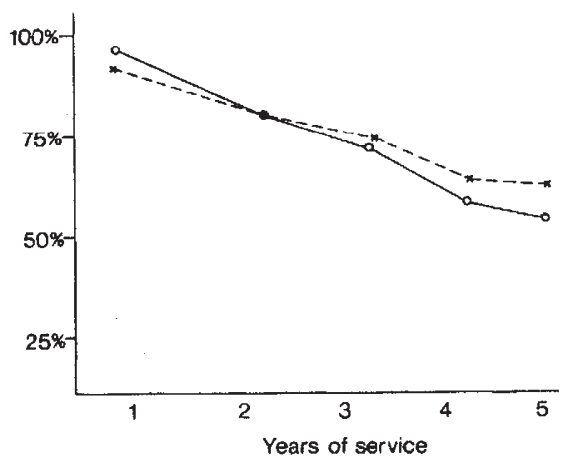

Fig. 1 Graduate retention. Taken from ref. 2.

that for social scientists $(£ 4,865)$ and just ahead of the arts and humanities graduates $(£ 4,672)$. The average salary across all subjects was $£ 5,058$. More than one in four of the CNAA scientists was unemployed ten months after graduation which is rather more than at the six months stage.

For graduates, like all other first time entrants into the labour market, the first job is only the first part of a career, the early years of which are likely to see several changes of job and possibly of employer. The first year for many can be a particularly difficult year of transition, especially, as in 1982, in times of a depressed labour market. The first destination statistics provide one snapshot, and give a limited performance measure; they do not however provide a complete picture of life after higher education.

\footnotetext{
1. Parsons. D. Graduate Recraiment and Retention 1980-84. IMS. 1985.
}

2. CNAA Graduate Survey. Interim Report. 1985

Richard Pearson is at the Institute of Manpower Studies. Mantell Building. University of Sussex, Brighton BNI $9 R F, U K$. 